
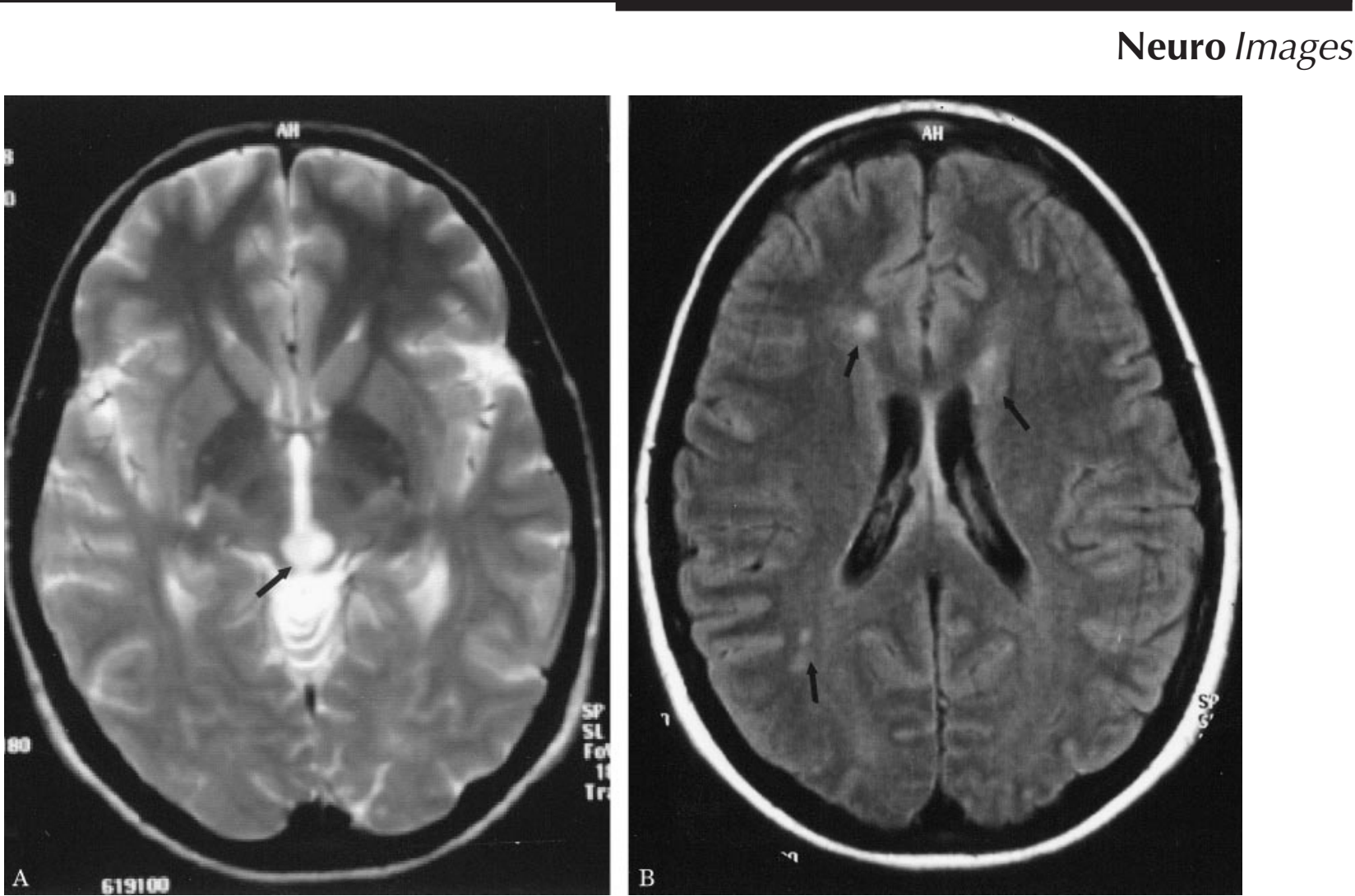

Figure. (A) Axial T2-weighted MRI of the head showing an intraparenchymal hyperintense signal abnormality in the superior colliculi (arrow). (B) Fluid-attenuated inversion recovery axial MRI of the head showing multiple hyperintense signal abnormalities throughout the cerebrum (arrows).

\section{Parinaud syndrome heralding MS}

William B. Lee, $M D$ and Joseph R. Berger, MD, Lexington, $K Y$; and Henry S. O'Halloran, FRCSI, MD, La Jolla, CA

A 32-year-old woman presented with diplopia and dizziness. Visual acuity was $20 / 25$ in the right eye and 20/20 in the left. Pupils showed light/near dissociation. She had marked limitation of elevation and convergence retraction nystagmus. Results of anterior segment and fundus examination were normal. MRI revealed an 8-mm intraparenchymal lesion involving the superior colliculi without mass effect (figure, A). The working diagnosis was a tectal plate glioma. One month later, MRI of the head was performed with

Address correspondence to Dr. William B. Lee, University of California, Davis Medical Center, 4860 Y Street, Suite 2400, Sacramento, CA 95817; e-mail: lee0003@aol.com; address reprint requests to Dr. Joseph R. Berger, Department of Neurology, Kentucky Clinic, 800 Rose Street, Lexington, KY 40536. spin echo and fluid-attenuated inversion recovery (FLAIR) axial images. The previously noted lesion measured 1.4 by $1 \mathrm{~cm}$ with new lesions in the right hippocampus, right frontal lobe, left centrum semiovale, right parietal lobe, and the genu of the corpus callosum (see figure, B).

MS occurs in association with dorsal midbrain syndrome, but seldom is a dorsal midbrain syndrome the presenting sign of MS. ${ }^{1,2}$ In our patient an isolated abnormality in the dorsal midbrain region was found at presentation, and the diagnosis of MS was delayed because of suspicion of a neoplasm. The initial MRI incorrectly suggested a neoplasm. Only after repeating the MRI with spin echo images and FLAIR axial images and CSF analysis was the diagnosis of MS evident.

1. Slyman JF, Kline LB. Dorsal midbrain syndrome in multiple sclerosis Neurology 1981;31:196-198.

2. Quint DJ, Cornblath WT, Trobe JD. Multiple sclerosis presenting as Parinaud syndrome. AJNR Am J Neuroradiol 1993;14:1200-1202. 


\section{Neurology}

Parinaud syndrome heralding MS

William B. Lee, Joseph R. Berger and Henry S. O'Halloran

Neurology 2003;60;322

DOI 10.1212/01.WNL.0000036304.22698.24

This information is current as of January 28, 2003

\section{Updated Information \&} Services

\section{References}

\section{Subspecialty Collections}

Permissions \& Licensing

Reprints including high resolution figures, can be found at: http://n.neurology.org/content/60/2/322.full

This article cites 2 articles, 2 of which you can access for free at: http://n.neurology.org/content/60/2/322.full\#ref-list-1

This article, along with others on similar topics, appears in the following collection(s):

All Imaging

http://n.neurology.org/cgi/collection/all_imaging

All Neuro-ophthalmology

http://n.neurology.org/cgi/collection/all_neuroophthalmology

MRI

http://n.neurology.org/cgi/collection/mri

Multiple sclerosis

http://n.neurology.org/cgi/collection/multiple_sclerosis

Ocular motility

http://n.neurology.org/cgi/collection/ocular_motility

Information about reproducing this article in parts (figures,tables) or in its entirety can be found online at:

http://www.neurology.org/about/about_the_journal\#permissions

Information about ordering reprints can be found online:

http://n.neurology.org/subscribers/advertise

Neurology ${ }^{\circledR}$ is the official journal of the American Academy of Neurology. Published continuously since 1951, it is now a weekly with 48 issues per year. Copyright . All rights reserved. Print ISSN: 0028-3878. Online ISSN: 1526-632X.

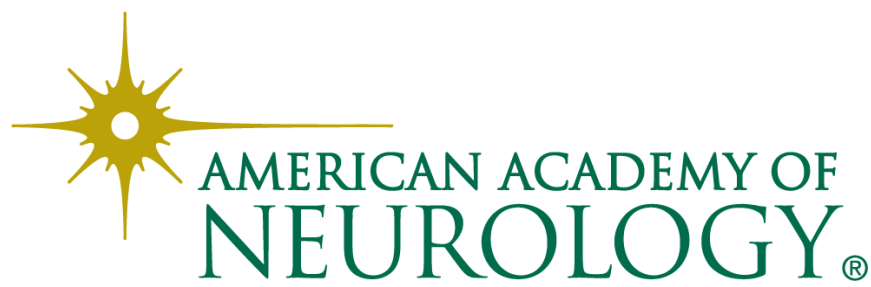

